\title{
Implementasi Sistem Informasi Akademik Berbasis Android pada SMA Negeri 1 Tempilang
}

\author{
Dwi Yuny Sylfania ${ }^{\# 1}$, Fransiskus Panca Juniawan ${ }^{\# 2}$, Leny Agusti ${ }^{\# 3}$ \\ ${ }^{\#}$ Teknik Informatika, STMIK Atma Luhur \\ Jl.Jend Sudirman, Selindung Baru, Pangkalpinang, Kepulauan Bangka Belitung \\ Idysylfanialatmaluhur.ac.id \\ fransiskus.pjeatmaluhur.ac.id \\ ${ }^{3}$ lenyagusti17@yahoo.co.id
}

\begin{abstract}
Abstrak - Sistem informasi akademik pada sebuah sekolah merupakan hal yang sangat penting, terlebih bagi pihak sekolah, siswa dan orangtua. Namun, penerapan sistem informasi akademik belum menjangkau seluruh institusi pendidikan, contohnya SMA Negeri 1 Tempilang. Sistem informasi akademik pada sekolah tersebut masih bersifat manual sehingga orangtua/wali siswa harus mendatangi sekolah secara langsung untuk memantau perkembangan akademik siswa. Oleh karena itu, penulis membangun sebuah aplikasi akademik berbasis Android, dimana para wali murid dan siswa bisa melihat informasi mengenai profil sekolah, jadwal mata pelajaran, absensi siswa dan raport siswa melalui aplikasi tanpa harus mendatangi sekolah. Penelitian ini menggunakan model penelitian waterfall dengan empat tahapan. Dengan adanya aplikasi akademik berbasis Android pada SMA Negeri 1 Tempilang diharapkan mampu mempermudah orangtua dan siswa dalam mendapatkan informasi akademik yang lebih akurat, efektif dan efisien, serta mempermudah pihak sekolah dalam mendistribusikan informasi mengenai perkembangan akademik siswa. Dari hasil pengujian Black Box didapat hasil bahwa sistem yang dibangun dapat bekerja dengan baik sesuai dengan fungsinya. Selain itu, penulis menyebarkan kuesioner untuk menguji kualitas dari sistem yang dibangun. Dari hasil pengujian kualitas sistem didapat hasil dengan nilai 3,05 yang artinya setuju terhadap kualitas sistem.
\end{abstract}

Kata kunci - Sistem Informasi Akademik, Android, Model Waterfall, Metode Berorientasi Objek, Black Box

\section{Pendahuluan}

Perkembangan sistem operasi Android sangat pesat dibandingkan sistem operasi lainnya. Android merupakan sistem operasi berbasis Linux yang digunakan untuk telepon seluler (mobile), seperti telepon pintar (smartphone) dan komputer tabet (PDA)[1]. Hal tersebut dikarenakan Android bersifat open source sehingga memudahkan para pengembang untuk membuat dan memodifikasi aplikasi atau fitur-fitur sesuai dengan keinginan.

Sistem informasi akademik adalah suatu sistem yang dirancang untuk keperluan pengelolaan data-data akademik dengan penerapan teknologi komputer baik hardware maupun software[2]. Sistem informasi akademik merupakan sesuatu yang sangat penting bagi pihak sekolah, orangtua dan siswa. Namun, penerapan sistem informasi akademik belum menjangkau seluruh institusi pendidikan, seperti SMA Negeri 1 Tempilang. Sistem informasi akademik pada sekolah tersebut masih bersifat manual, sehingga informasi perkembangan siswa hanya dapat dipantau dengan mendatangi sekolah secara langsung.

Berdasarkan latar belakang di atas, penulis membangun sebuah aplikasi akademik berbasis Android dengan menggunakan model waterfall dan metode berorientasi objek. Definisi dari model waterfall adalah proses hidup perangkat lunak yang memiliki sebuah proses yang linear dan sekuensial [3]. Dalam penelitian ini, penulis memulai tahapan dari analisa, perancangan, implementasi dan pengujian. Adapun pengujian yang digunakan yaitu pengujian Black Box untuk memeriksa apakah aplikasi berjalan seperti yang diharapkan [4]. Selain itu, pengujian kualitas sistem yang dibangun dilakukan dengan cara menyebarkan kuesioner kepada responden.

Adapun penelitian yang dijadikan sebagai referensi adalah penelitian yang dilakukan oleh [5] menghasilkan sistem informasi pelayanan obat pada apotek sehingga memudahkan dalam mencari informasi mengenai obat dan stok obat yang akan dicari. Penelitian [6] menghasilkan aplikasi repository digital beban kerja dosen yang dapat membantu dosen dalam mengetahui beban kerja yang ditanggung dan membantu pimpinan dalam mengetahui informasi beban kerja yang ditanggung setiap dosen. Penelitian [7] menghasilkan sistem informasi untuk monitoring data terkait distribusi obat di Indonesia, serta mampu memberikan notifikasi sehingga dapat mengurangi terjadinya kesalahan dan kecurangan yang terjadi dalam proses distribusi obat. Penelitian [8] menghasilkan sistem informasi penjualan tunai yang terkomputerisasi yang dapat meningkatkan kualitas pelayanan kepada pembeli, membuat laporan cepat, tepat dan akurat, meminimalkan kesalahan (redudansi) dalam 
pengumpulan data, dan penyimpanan data lebih terstruktur dan mampu meningkatkan efisiensi dan efektivitas proses penjualan tunai. Penelitian [9] menghasilkan sistem informasi perkawinan yang terkomputerisasi sehingga penerbitan kutipan akta perkawinan dapat dengan cepat diterbitkan sehingga pelayanan kepada masyarakat lebih cepat dan maksimal, pembuatan laporan menjadi cepat, penyimpanan data lebih terorganisir serta dapat meningkatkan kinerja karyawan pada Dinas Kependudukan dan Pencatatan Sipil Kota Pangkalpinang. Penelitian [10] dengan menggunakan kerangka kerja Weill-Ross menghasilkan sebuah model tata kelola yang sesuai dengan kebutuhan dan kondisi penerapan teknologi informasi di Itenas Bandung. Penelitian [11] dengan menggunakan framework TOGAF menghasilkan sistem informasi bagi tiap sub bagian pada STD Bali sehingga meningkatkan kinerja di tiap sub bagian untuk menghasilkan informasi yang relevan, akurat dan tepat waktu. Penelitian [12] menghasilkan sebuah pembuktian bahwa database tidak hanya berfungsi sebagai penyimpanan data, tetapi juga dapat mengendalikan sistem informasi secara aktif. Hal ini dikarenakan logika dan aturan bisnis yang tersimpan pada database mampu memantau seluruh sistem dan memastikan pemrosesan data berjalan dengan benar. Penelitian [13] menghasilkan sistem absensi siswa yang lebih terkomputerisasi sehingga memudahkan orangtua dalam mendapatkan informasi siswa di sekolah. Penelitian [14] dengan menggunakan primary key yang telah direncanakan dengan baik mampu mengurangi redundansi data sehingga integritas data pada sistem informasi akademik terjaga. Selain mempermudah dalam mencari kumpulan - kumpulan jurnal, sistem e-journal berbasis web pada STMIK Raharja juga mempermudah dalam penulisan jurnal [15]. Penerapan official site jurusan sistem informasi dijadikan sebagai wadah bagi mahasiswa untuk mendapatkan informasi yang akurat, serta dengan strategi memperkaya inbound website sistem informasi mampu memperkenalkan keberadaan website ke khalayak ramai untuk meningkatkan peringkat STMIK Raharja di webometrics [16]. Penerapan ITIL Framework pada sistem informasi akademik mampu mengelola sumber daya secara tepat sehingga cepat dan mudah dalam mengelola insiden yang muncul pada sistem informasi akademik [17]. Berdasarkan penerapan ISO/IEC 9126, diperoleh tiga karakteristik yang perlu ditingkatkan yaitu reliability, usability dan functionality. Hasil dari pengujian reliability tidak dapat diandalkan karena tidak termasuk dalam proses analisis dan rekomendasi untuk pengembangan lebih lanjut [18]. Kualitas sistem informasi akademik terhadap kepuasan pengguna di UPI yang dianalisis menggunakan Gap dan SEM menghasilkan kepuasan responden terhadap implementasi sistem informasi akademik, dan tiap variabel dan indikator memiliki hubungan yang signifikan dan pengaruh cukup besar terhadap kepuasan pengguna[19].
Oleh karena itu, dengan adanya sistem informasi akademik berbasis Android pada SMA Negeri 1 Tempilang diharapkan memudahkan orangtua dan siswa dalam mendapatkan informasi akademik yang lebih akurat, efektif dan efisien serta memudahkan pihak sekolah dalam mendistribusikan informasi perkembangan akademik siswa.

\section{Metodologi Penelitian}

Model yang digunakan dalam penelitian ini adalah model waterfall. Adapun tahapan yang dilakukan dalam penelitian ini terdapat pada gambar 1 .

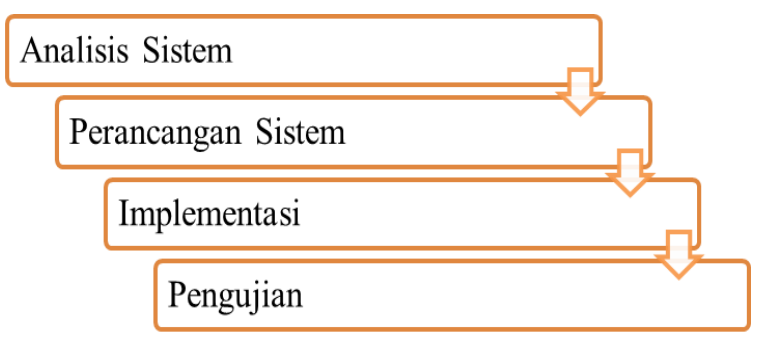

Gambar. 1 Tahapan Penelitian

\section{A. Analisis Sistem}

Pada tahapan ini menguraikan analisis sistem berjalan dengan menggunakan activity diagram, seperti proses pemberian nilai pada raport, pembuatan jadwal mata pelajaran, informasi mengenai sekolah, absensi dan biodata siswa.

\section{B. Perancangan Sistem}

Tahapan perancangan sistem akan menggambarkan fungsionalitas dari sistem yang akan dibangun secara keseluruhan yang didapat dari hasil analisis sistem sebelumnya, dan dijelaskan dengan menggunakan use case diagram.

\section{Implementasi}

Pada tahap ini, berisi screenshot aplikasi yang merupakan hasil dari perancangan sistem.

\section{Pengujian}

Pada penelitian ini, penulis menggunakan pengujian Black Box untuk menguji kesesuaian input yang diberikan dengan output yang dihasilkan oleh sistem. Selain itu, penulis melakukan pengujian kualitas sistem dengan menyebarkan kuesioner.

Kuesioner menggunakan Skala Likert 1-5 dengan nilai 1 berupa Sangat Tidak Setuju dan nilai 5 berupa Sangat Setuju. Hasil perhitungan kuesioner dihitung menggunakan rumus sebagai berikut:

$$
T n=R * P n
$$

Dengan:

$T n=$ Total Nilai

$R \quad=$ Total Responden 
$P n=$ Pilihan angka skor likert

Kemudian keseluruhan $T n$ yang ada sesuai hasil Skala Likert yang diisi responden sehingga didapat $T_{\text {tot. }}$

\section{HASIL DAN PEMBAHASAN}

Berdasarkan hal di atas, adapun hasil dan pembahasan dari penelitian yaitu sebagai berikut:

\section{A. Analisis Sistem}

Pada tahap ini menggambarkan hasil dari analisis sistem berjalan pada SMA Negeri 1 Tempilang dan dijelaskan dengan menggunakan activity diagram.

Gambar 2 menjelaskan alur proses dalam hal pendistribusian informasi sekolah kepada siswa/ wali siswa, yang melibatkan kepala sekolah dan tata usaha. Pada Gambar 3, menjelaskan alur proses dalam pengumpulan biodata siswa. Selanjutnya, menjelaskan proses pembuatan jadwal mata pelajaran, yang ditunjukkan pada Gambar 4. Alur proses absensi siswa dan raport siswa ditunjukkan pada Gambar 5 dan Gambar 6 , yang melibatkan guru, wali kelas dan siswa/wali siswa.

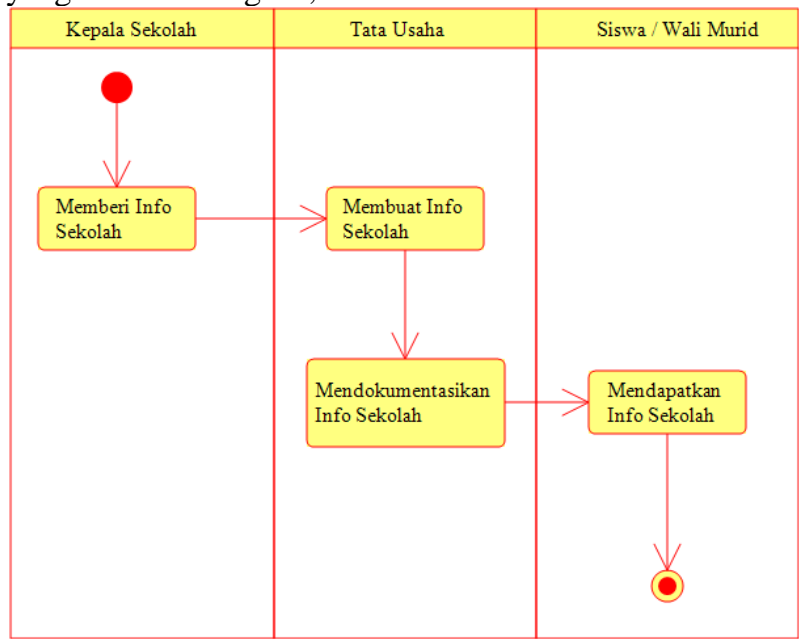

Gambar. 2 Activity Diagram Informasi Sekolah

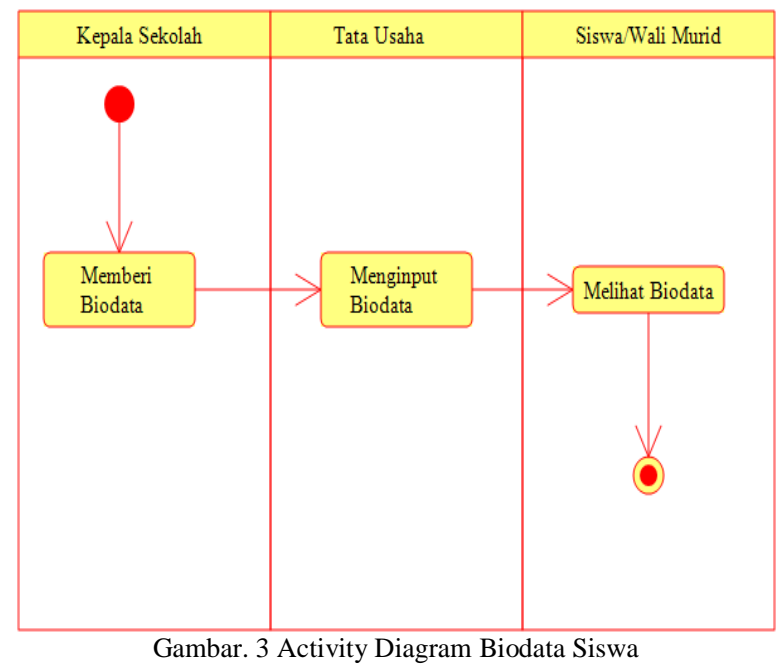

Gambar. 3 Activity Diagram Biodata Siswa

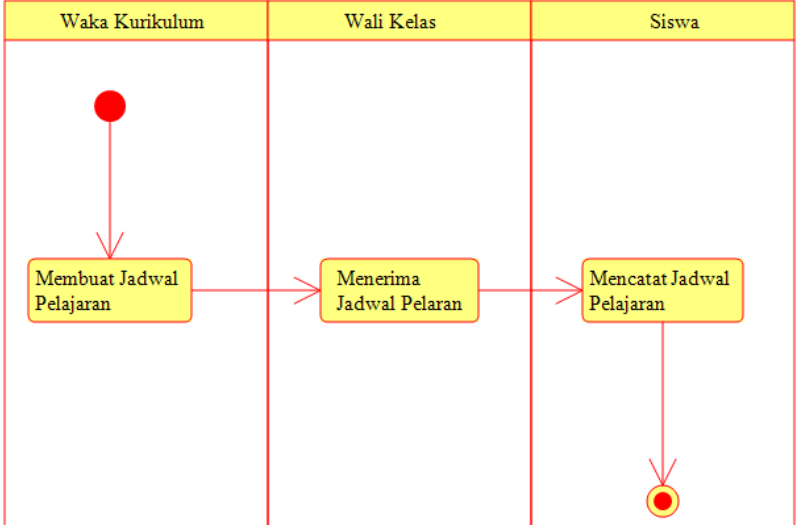

Gambar. 4 Activity Diagram Jadwal Mata Pelajaran

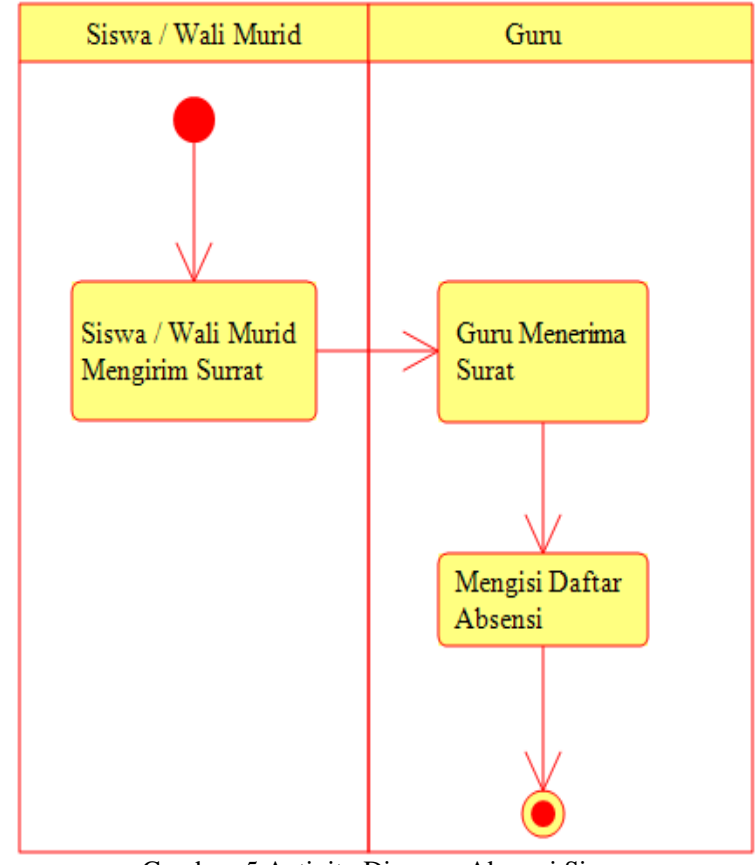

Gambar. 5 Activity Diagram Absensi Siswa

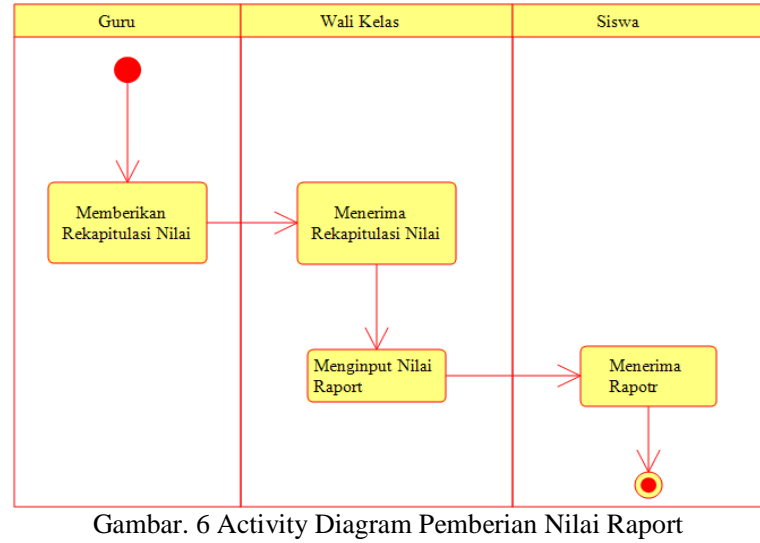

\section{B. Perancangan Sistem}

Pada tahap ini menggambarkan rancangan sistem pada SMA Negeri 1 Tempilang dengan menggunakan use case diagram.

Pada Gambar 7, terdapat 2 (dua) aktor, yaitu admin dan user, dimana admin merupakan aktor aktif, sedangkan 
user merupakan aktor pasif. Tidak seperti user yang hanya bisa mengakses, namun admin juga bisa mengelola seluruh menu pada sistem informasi akademik, namun aktor (admin dan user) harus terlebih dahulu login ke sistem, dengan menginput username (bagi admin), nisn (bagi user) dan password terlebih dahulu agar bisa masuk ke menu utama. Setelah user/admin berhasil login, maka sistem akan menampilkan informasi mengenai sekolah yang berisi visi dan misi SMA Negeri 1 Tempilang. Pada menu biodata siswa, user hanya bisa melihat biodata, sedangkan admin bertugas mengelola (menambah, mengubah, menghapus, dan melihat) biodata siswa yang ada di dalam database. Selanjutnya, untuk menu jadwal mata pelajaran, admin bertugas mengelola (menambah, mengubah, menghapus dan melihat) jadwal mata pelajaran. Namun, user hanya bisa melihat jadwal mata pelajaran dengan terlebih dahulu menginput kode hari, kode kelas dan tahun ajaran. Pada use case absensi dan pemberian nilai raport, admin bertugas mengelola (menambah, mengubah, menghapus dan melihat) absensi dan raport siswa, sedangkan user hanya bisa melihat absensi dan raport siswa. Pada menu pengaturan akun, admin memiliki wewenang penuh untuk reset akun user, jika sewaktu-waktu user lupa dengan akunnya.

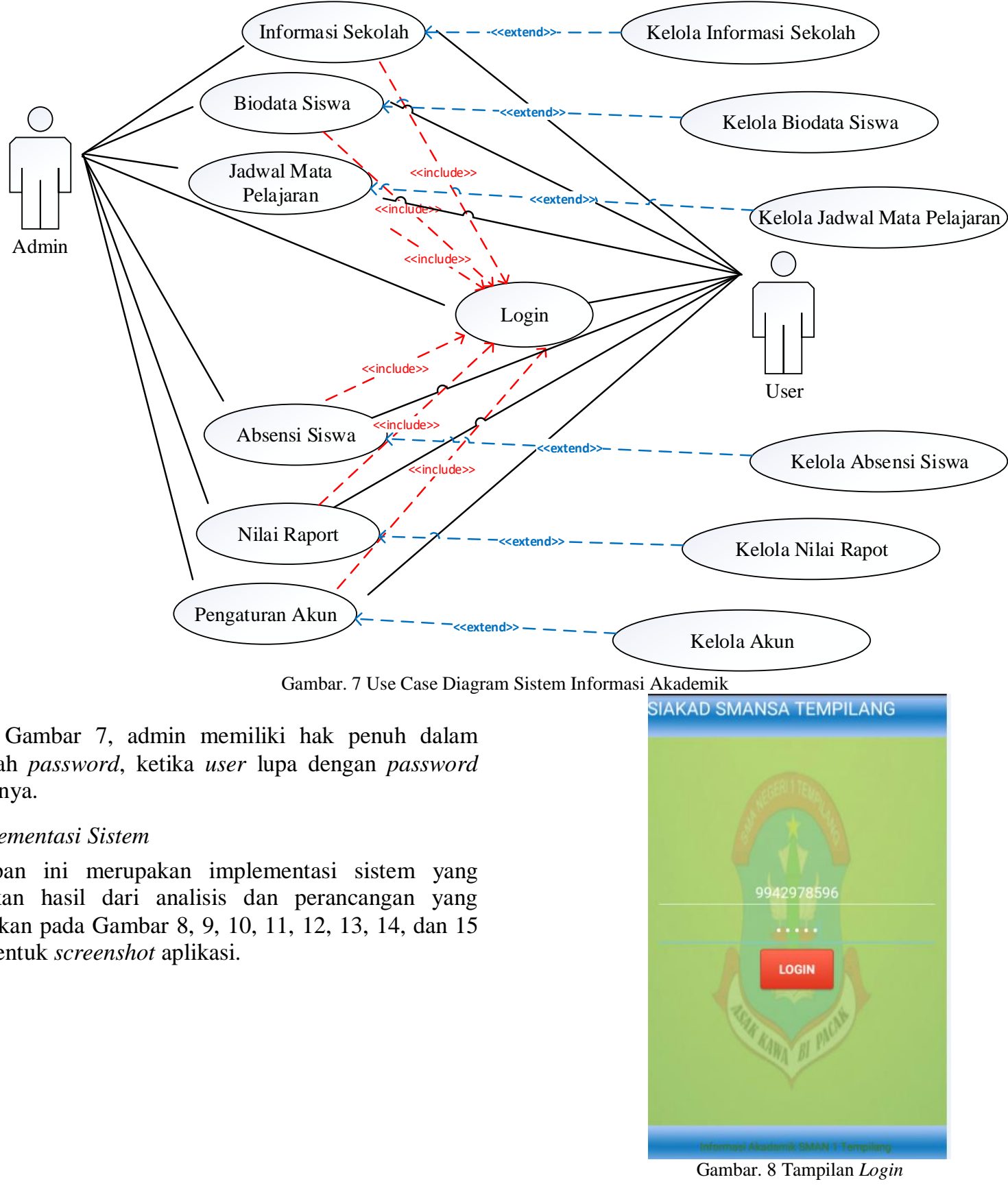




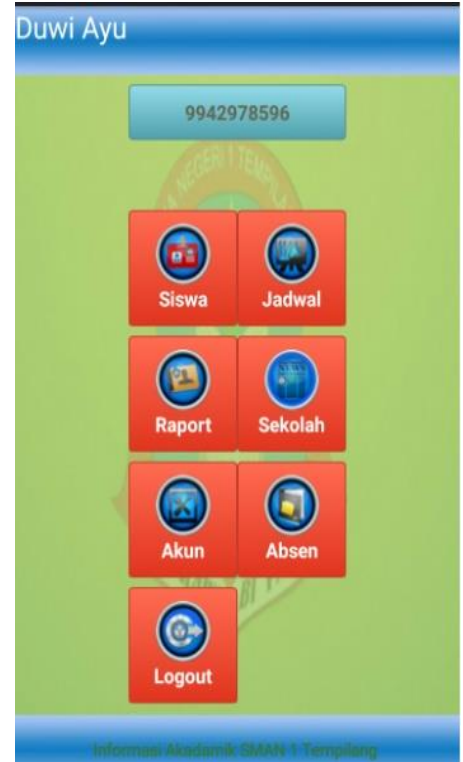

Gambar. 9 Tampilan Menu Utama
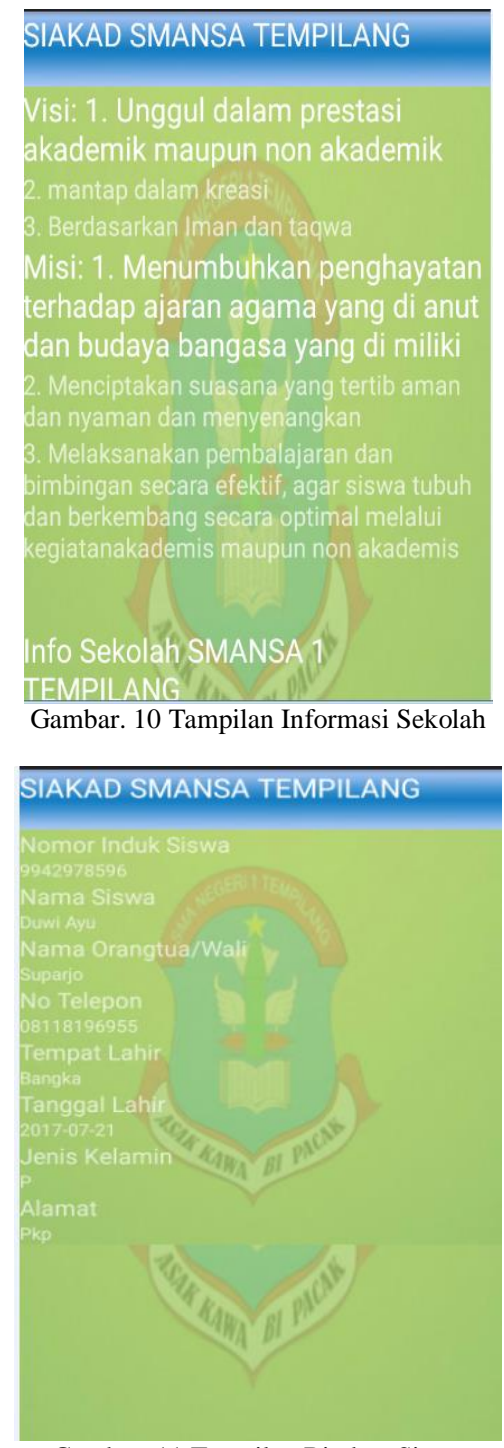

Gambar. 11 Tampilan Biodata Siswa
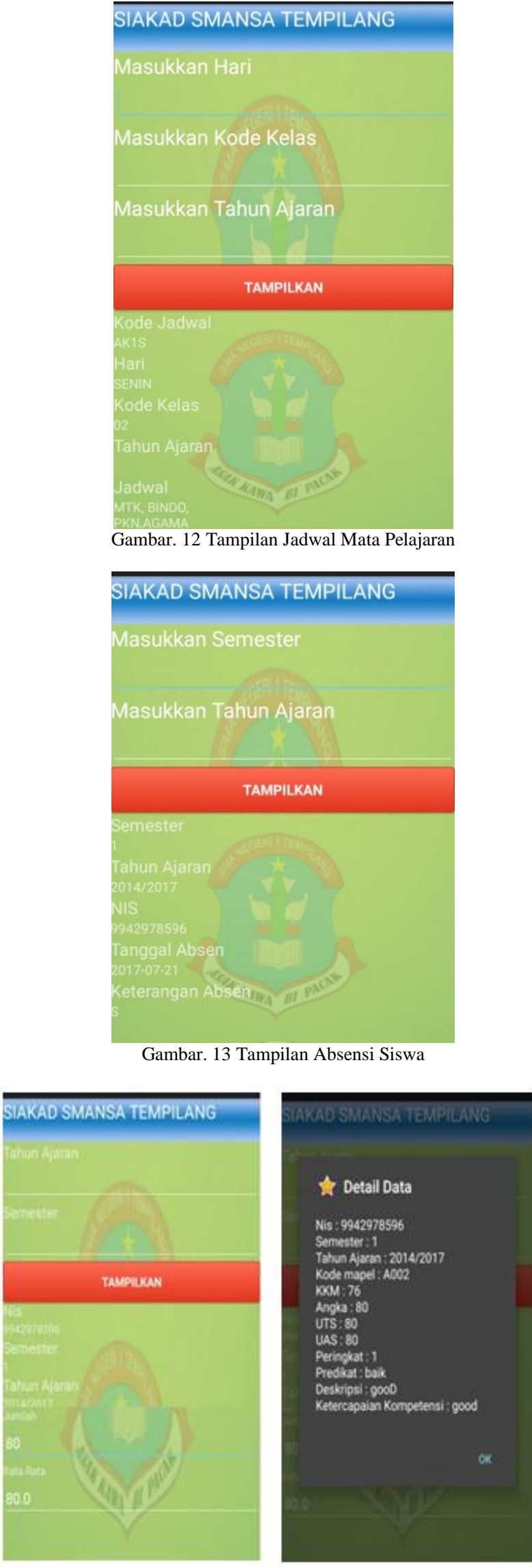

Gambar. 14 Tampilan Raport 


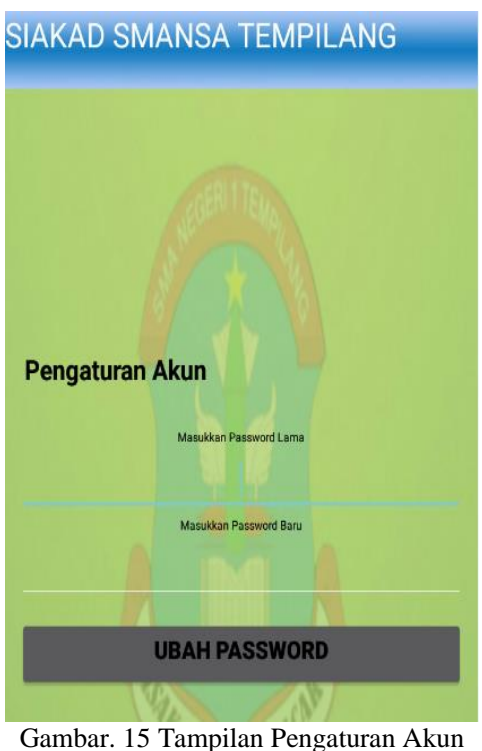

\section{Pengujian Sistem}

Pada tahap pengujian sistem dilakukan dengan menggunakan Black Box, dan juga dilakukan pengujian kualitas sistem dengan penyebaran kuesioner kepada responden.

1) Pengujian Black Box pengujian ini digunakan untuk menguji kesesuaian input yang diberikan user dengan output yang dihasilkan oleh sistem, ditunjukkan pada Tabel 1.

TABEL I

PENGUJIAN BLACK BoX

\begin{tabular}{|c|c|c|c|}
\hline No & Test Case & Hasil yang diharapkan & Keterangan \\
\hline 1 & $\begin{array}{l}\text { Pengujian } \\
\text { Tombol Login }\end{array}$ & $\begin{array}{l}\text { Sistem akan memproses } \\
\text { data login dan masuk ke } \\
\text { menu utama }\end{array}$ & Valid \\
\hline 2 & $\begin{array}{l}\text { Pengujian } \\
\text { Tombol Jadwal } \\
\text { Matapelajaran }\end{array}$ & $\begin{array}{l}\text { Sistem akan masuk ke } \\
\text { dalam form jadwal } \\
\text { pelajaran dan akan } \\
\text { menampilkan jadwal } \\
\text { pelajaran apabila pengguna } \\
\text { sudah menginput hari, } \\
\text { kode kelas,tahun ajaran } \\
\text { dengan benar. }\end{array}$ & Valid \\
\hline 3 & $\begin{array}{l}\text { Pengujian } \\
\text { Tombol Nilai } \\
\text { Raport }\end{array}$ & $\begin{array}{l}\text { Sistem akan masuk ke } \\
\text { dalam form Nilai Raport } \\
\text { dan akan menampilkan } \\
\text { raport, jika sudah } \\
\text { memasukkan semester dan } \\
\text { tahun ajaran dengan benar. }\end{array}$ & Valid \\
\hline 4 & $\begin{array}{l}\text { Pengujian } \\
\text { Tombol Absen }\end{array}$ & $\begin{array}{l}\text { Sistem akan masuk ke } \\
\text { dalam form absen dan akan } \\
\text { menampilkan absen setelah } \\
\text { menginput semester dan } \\
\text { tahun ajaran dengan benar }\end{array}$ & Valid \\
\hline 5 & $\begin{array}{l}\text { Pengujian } \\
\text { Biodata }\end{array}$ & $\begin{array}{l}\text { Sistem akan masuk ke } \\
\text { form biodata, kemudian } \\
\text { menampilkan } \\
\text { siswa. }\end{array}$ & Valid \\
\hline 6 & $\begin{array}{ll}\text { Pengujian } & \\
\text { Tombol } & \text { Info } \\
\end{array}$ & $\begin{array}{lrr}\text { Sistem } & \text { akan } & \text { masuk ke } \\
\text { form } & \text { info } & \text { sekolah, }\end{array}$ & Valid \\
\hline
\end{tabular}

\begin{tabular}{|l|l|l|l|}
\hline No & Test Case & Hasil yang diharapkan & Keterangan \\
\hline & Sekolah & $\begin{array}{l}\text { kemudian menampilkan } \\
\text { info sekolah }\end{array}$ & \\
\hline 7 & $\begin{array}{l}\text { Pengujian } \\
\text { Tombol Ubah } \\
\text { Akun }\end{array}$ & $\begin{array}{l}\text { Sistem akan masuk ke } \\
\text { ubah akun dan ada pilihan } \\
\text { masukkan password lama } \\
\text { dan masukkan password } \\
\text { baru. }\end{array}$ & Valid \\
\hline
\end{tabular}

2) Pengujian Kualitas Sistem: pengujian ini dilakukan dengan menyebarkan kuesioner kepada 10 responden dengan 4 pertanyaan, dan 4 skala nilai dimulai dari rentang 1 hingga 4, yaitu tidak setuju, kurang setuju, setuju dan sangat setuju, ditunjukkan pada Tabel 2 dan Gambar 22. Daftar pertanyaan ditampilkan pada Tabel 3.

TABEL II

PENGUJian KuALITAS Sistem

\begin{tabular}{|l|c|c|c|c|}
\hline \multirow{2}{*}{ Responden } & \multicolumn{5}{|c|}{ Pertanyaan } \\
\cline { 2 - 5 } & $\mathbf{1}$ & $\mathbf{2}$ & $\mathbf{3}$ & $\mathbf{4}$ \\
\hline Aulia & 3 & 3 & 4 & 3 \\
\hline Sinta & 3 & 4 & 3 & 3 \\
\hline Silvi & 3 & 2 & 2 & 3 \\
\hline Dara & 3 & 3 & 4 & 3 \\
\hline Puspita & 3 & 2 & 3 & 3 \\
\hline Sartono & 3 & 4 & 3 & 3 \\
\hline Margono & 3 & 3 & 2 & 3 \\
\hline Indra & 3 & 3 & 4 & 3 \\
\hline Yoman & 3 & 2 & 3 & 3 \\
\hline Kusnaedi & 3 & 4 & 4 & 3 \\
\hline Total & $\mathbf{3 0}$ & $\mathbf{3 0}$ & $\mathbf{3 2}$ & $\mathbf{3 0}$ \\
\hline Rata-rata & $\mathbf{3}$ & $\mathbf{3}$ & $\mathbf{3 . 2}$ & $\mathbf{3}$ \\
\hline
\end{tabular}

TABEL III

DAFTAR PERTANYAAN

\begin{tabular}{|l|l|}
\hline Nomor & \multicolumn{1}{|c|}{ Pertanyaan } \\
\hline Pertanyaan 1 & $\begin{array}{l}\text { Apakah aplikasi dapat menyajikan informasi } \\
\text { akademik secara cepat, tepat dan akurat? }\end{array}$ \\
\hline Pertanyaan 2 & $\begin{array}{l}\text { Apakah aplikasi mampu menghemat waktu dan } \\
\text { biaya? }\end{array}$ \\
\hline Pertanyaan 3 & $\begin{array}{l}\text { Apakah aplikasi mempermudah penginputan data } \\
\text { seperti raport, absen, dan jadwal mata pelajaran? }\end{array}$ \\
\hline Pertanyaan 4 & Apakah aplikasi mudah digunakan? \\
\hline
\end{tabular}

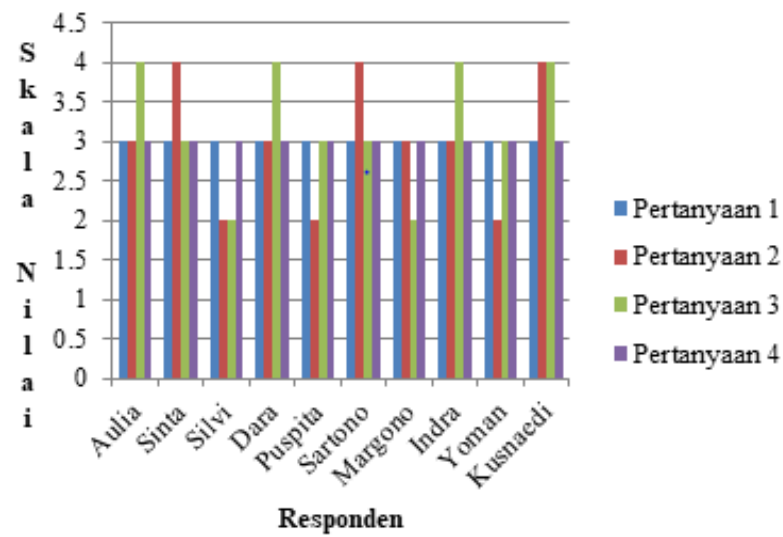

Gambar 16 Grafik Penilaian Responden Terhadap Kualitas Sistem

\section{KESIMPULAN}

Berdasarkan hasil pengujian Black Box dan pengujian kualitas sistem dengan kuesioner, aplikasi sistem 
informasi akademik berbasis Android pada SMA Negeri 1 Tempilang mampu memudahkan orangtua dan siswa dalam memperoleh informasi akademik yang lebih akurat dan efisien. Selain itu, aplikasi ini juga memudahkan pihak sekolah dalam mendistribusikan informasi mengenai perkembangan akademik siswa. Sesuai dengan hasil dari Tabel 2 dengan nilai rataan adalah 3,05 (setuju).

\section{REFERENSI}

[1] Y. Supardi, Koleksi Program Tugas Akhir dan Skripsi dengan Android, Jakarta: Elex Media Komputindo, 2017.

[2] A. Kadir, Pengenalan Sistem Informasi, Yogyakarta : Andi, 2009

[3] S. R. Wicaksono, Rekayasa Perangkat Lunak, Malang : Seribu Bintang, 2017.

[4] J. Simarmata, Rekayasa Perangkat Lunak, Yogyakarta : Andi, 2010.

[5] R. Anindita, P. Nurul, P. Rachmatullah, S. Akbar, S. Permata, dan S. Mulyaningsih, "Analisis dan Perancangan Sistem Informasi Pelayanan Obat di Apotek Generik", JEPIN, vol. 2, no. 1, pp. $21-26$, Juni. 2016

[6] M. A. Irwansyah, "Sistem Informasi Repository Digital Beban Kerja Dosen", JEPIN, vol. 1, no. 1, pp. 18 -23, Juni. 2015.

[7] Y. Amelia, Albarda, dan E. Trinovani, "Sistem Informasi Untuk Monitoring Distribusi Obat di Indonesia", JEPIN, vol. 1, no. 1, pp. $45-52$, Juni. 2015 .

[8] D. Y. Sylfania, "Rancangan Sistem Informasi Penjualan Tunai Pada Fajar Indah Motor Dengan Metodologi Berorientasi Obyek", SISFOKOM, vol. 6, no. 2, pp. 137 - 143, September. 2017.

[9] O. Rizan, Hamidah, dan I. Yuniarti, “Analisis dan Perancangan Sistem Informasi Perkawinan Non-Muslim Pada Dinas Kependudukan dan Catatan Sipil Pangkalpinang", TEKNOSI, vol. 03, no. 1, pp. $51-60$, April. 2017.

[10] R. Budiraharjo, "Penerapan Weill-Ross Model Dalam Tata Kelola Teknologi Informasi di Perguruan Tinggi”, TEKNOSI, vol. 3, no. 1, pp. $109-116$, April. 2017.
[11] S. I. Murpratiwi, A. W. Gustina, and I. C. Dewi, "Design of Enterprise Information System with TOGAF Framework (Case Study : STD Bali)", International Journal of Engineering and Emerging Technology, vol. 1, no. 1, pp. $20-25$, July December. 2016.

[12] M. M. Amin, A. Maseleno, K. Shankar, E. Perumal, R. M Vidhyavathi, and S. K. Lakshmanaprabu, "Active Database System Approach and Rule Based in the Development of Academic Information System", International Journal of Engineering and Technology, vol. 7, no. 2. 26, pp. $95-101$. 2018.

[13] T. Susilowati, M. I. Dacholfany, S. Aminin, A. Ikhwan, B. M. Nasir, M. Huda, A. Prasetyo, A. Maseleno, F. Satria, S. Hartati, and Wulandari, "Getting Parents Involved in Child's School : Using Attendance Application System Based on SMS Gateway", International Journal of Engineering and Technology, vol. 7, no. 2. 27 , pp. $167-174.2018$

[14] E. Utami, and S. Raharjo, "Database Security Model in the Academic Information System", International Journal of Security and Its Applications, vol. 8, no. 3, pp. 163 - 174. 2014.

[15] Faridi, P. Aripianti, dan R. Widuri, "Perancangan Sistem Informasi E-Jurnal Pada Perguruan Tinggi Berbasis Web", CERITA, vol. 2, no. 2, pp. 189 - 198, Agustus. 2016.

[16] U. Rahardja, Q. Aini, dan L. R. Sulastrini, "Penerapan Inbound Official Site Sistem Informasi Untuk Meningkatkan Rank Webometrics", Technomedia Journal, vol. 1, no. 2, pp. 105 115, Oktober. 2017.

[17] V. R. Palilingan and J. R. Batmetan, "Incident Management in Academic Information System Using ITIL Framework", in International Conference on Innovation in Engineering and Vocational Education, 2018, pp. 1 - 9.

[18] D. D. J. Suwawi, E. Darwiyanto, and M. Rochmani, "Evaluation of Academic Website Using ISO/IEC 9126", in IEEE International Conference on Information and Communication Technology, 2015, pp. 222 - 227.

[19] Sultono, A. K. B. Seminar, and Erizal, "Analysis on Academic Information System Quality Toward User Satisfaction", International Journal of Administrative Science \& Organization, vol. 22, no. 2, pp. $122-129$, May. 2015. 